\title{
SERTIFIKAT HAK MILIK ATAS TANAH SEBAGAI ALAT BUKTI HAK YANG KUAT
}

\author{
CERTIFICATE OF THE PROPERTY RIGHT AS AN EVIDENCE OF \\ POWERFULL RIGHT
}

\author{
Dadi Arja Kusuma, Rodliyah, Sahnan \\ Magister Kenotariatan Universitas Mataram \\ Email: arjadadi@gmail.com \\ Naskah diterima : 17/06/2017; revisi : 25/07/2017; disetujui : 25/08/2017
}

\begin{abstract}
One of the objectives of land registration is to provide legal certainty and legal protection for holders right of land certificate who has good faith. Purposes of this study are to examine and analyze the criteria of certificates as a strong evidence, and legal protection for the holder of the certificate who has good faith. This type of legal research is normative research. The theory used in this research is theory of legal certainty, law enforcement theory, authority theory and legal protection theory. The approach of this research are legislation approach, conceptual approach and case approach. Based on results of the research showed that the criteria of certificates as a strong evidence of rights are: the issuance of right of land certificates must through the use of applicable regulatory procedures, the Certificate made by the good faith Right Holder, issued by the authorized institution and the land object controlled significantly for more than 5 (five) years. Legal protection for the holder of the certificate who has good faith are preventively pursuant to Article 32 (1) and (2) Government Regulation Number 24 year 1997 and repressively by the recstverwerking institution and especially on civil case number: 10 / Pdt.G / 2010 / PN.SBB the holder of certificate who has good faith given repressive legal protection.
\end{abstract}

Keywords: Certificate, Strong Evidence, Protection

\section{Abstrak}

Salah satu tujuan dari pendaftaran tanah adalah memberikan kepastian hukum dan perlindungan hukum bagi pemegang sertifikat hak milik atas tanah yang beriktikad baik. Adapun tujuan penelitian ini adalah untuk mengkaji dan menganalisis kriteria-kriteria sertifikat sebagai alat bukti yang kuat, dan perlindungan hukum bagi pemegang sertifikat yang beriktikad baik. Tipe penelitian hukum ini adalah penelitian normatif. Teori yang digunakan dalam penelitian ini adalah teori kepastian hukum, teori penegakkan hukum, teori kewenangan dan teori perlindungan hukum. Metode pendekatan yang digunakan adalah pendekatan perundang-undangan, konseptual dan pendekatan kasus. Berdasarkan hasil penelitian bahwa kriteria-kriteria sertifkat sebagai alat bukti hak yang kuat yakni penerbitan sertifikat hak milik atas tanah harus melalui prosedur peraturan yang berlaku, Sertifikat di buat oleh Pemegang Hak yang beriktikad baik, diterbitkan instansi yang berwenang dan obyek tanah dikuasai secara nyata selama lebih dari 5 (lima) tahun. Perlindungan hukum bagi pemegang sertifikat yang beriktikad baik yaitu secara preventif berdasarkan ketentuan pasal 32 ayat 1 dan 2 PP No 24 tahun 1997 dan represif dengan adanya lembaga recstverwerking, dan khususnya pada perkara perdata nomor :10/Pdt.G/2010/PN.SBB diberikan perlindungan hukum secara represif bagi pemegang sertifikat yang beriktikad baik.Kata

Kunci : Sertifikat, Alat Bukti Kuat, Perlindungan 


\section{PENDAHULUAN}

Peraturan Pemerintah Nomor 24 Tahun 1997 tentang Pendaftaran Tanah mengatur bahwa pendaftaran tanah adalah rangkaian kegiatan yang dilakukan oleh Pemerintah secara terus-menerus, berkesinambungan dan teratur, meliputi pengumpulan, pengolahan, pembukuan dan penyajian serta pemeliharaan data fisik dan data yuridis dalam bentuk peta dan daftar, mengenai bidang-bidang tanah dan satuansatuan rumah susun, termasuk pemberian surat tanda bukti haknya bagi bidangbidang tanah yang sudah ada haknya dan hak milik atas satuan rumah susun serta hak-hak tertentu yang membebaninya.. Adapun pentingnya pendaftaran tanah tersebut menurut Pasal 3 PP No.24 Tahun 1997, disebutkan sebagai berikut:

1. Untuk memberikan kepastian hukum dan perlindungan hukum kepada pemegang hakatassuatubidangtanah. Satuanrumah susun dan hak-hak lain yang terdaftar agar dengan mudah dapat membuktikan dirinya sebagai pemegang hak yang bersangkutan.

2. Untuk menyediakan informasi kepada pihak-pihak yang berkepentingan termasuk pemerintahan agar dengan mudah dapat memperoleh data yang diperlukan dalam mengadakan perbuatan hukummengenaibidang-bidangtanahdan satuan-satuan rumah susun yang sudah terdaftar.

3. Untuk terselenggaranya tertib administrasi.

Untuk menjamin kepastian hukum hakhak atas tanah, maka pendaftaran tanah harus meliputi: ${ }^{1}$

a. Kadaster hak yaitu kegiatan pengukuran dan pemetaan bidang-bidang tanah hak dan pendaftaran bidang-bidang tersebut

${ }^{1}$ Boedi Harsono, Hukum Agraria Indonesia, Jakarta, 2007, Hlm 78.

310 IUS Kajian Hukum dan Keadilan dalam daftar-daftar tanah. Bidang-bidang tanah hak adalah bidang-bidang yang dimiliki orang atau badan hukum dengan suatu hak.

b.Pendaftaranhakyaitukegiatanpendaftaran hak-hak dalam daftar buku tanah atas pemegang haknya.

Peraturan Pemerintah Nomor 24 Tahun 1997 tentang Pendaftaran Tanah tetap mempertahankan tujuan dan sistem yang digunakan dalam Pasal 19 UUPA jo PP Nomor 10 Tahun 1961. PP Nomor 24 Tahun 1997 merupakan penyempurnaan dari peraturan sebelumnya. Salah satunya terdapat dalam Pasal 32 yang mengatur bahwa :

(1) Sertifikat merupakan surat tanda bukti hak yang berlaku sebagai alat pembuktian yang kuat mengenai data fisik dan data yuridis yang termuat di dalamnya, sepanjang datafisik dan data yuridistersebutsesuaidengandatayang ada dalam surat ukur dan buku tanah hak yang bersangkutan.

(2) Dalam hal suatu bidang tanah sudah diterbitkan sertifikat secara sah atas nama orang atau badan hukum yang memperoleh tanah tersebut dengan itikad baik dan secara nyata menguasainya, maka pihak lain yang merasa mempunyai hak atas tanah itu tidak dapat lagi menuntut pelaksanaan hak tersebut apabila dalam jangka waktu (5) lima tahun sejak diterbitkannya sertifikat itu tidak mengajukan keberatan secara tertulis kepada pemegang sertifikat dan kepala Kantor Pertanahan yang bersangkutan ataupun tidak mengajukan gugatan ke Pengadilan mengenai penguasaan tanah atau penerbitan sertifikat tersebut.

Meskipun kepemilikan tanah telah diatur sedemikian rupa, namun masih saja terdapat permasalahan dalam hal kepemilikan 
sebidang tanah, misalnya saja terhadap sebidang tanah yang sudah dikuasai oleh subjek hukum selama bertahun-tahun dan telah dilengkapi dengan sertifikat. Terhadap tanah itu masih ada pihak luar yang menuntut hak atas tanah tersebut.

Maka dari itu, sangat pentingnya diberikan suatu perlindungan hukum bagi pemegang sertifikat ham milik atas tanah yang beritikad baik yang telah menguasai tanah secara nyata selama bertahuntahun terhadap tanah yang dikelola dan dikuasainya dari keberatan-keberatan dan upaya-upaya yang dilakukan oleh pihak luar.

Rumusan masalah yang digunakan; Pertama, Apa kriteria-kriteria sertifikat hak milik atas Tanah sebagai alat bukti hak yang kuat? dan kedua, Bagaimana perlindungan hukum bagi pemegang sertifikat yang beritikad baik?

Bertitik tolak dari rumusan masalah yang telah dipaparkan, maka tujuan penelitian ini adalah ; Pertama, Untuk mengkaji dan kriteria-kriteria sertifikat hak milik atas Tanah sebagai alat bukti hak yang kuat. Kedua, Untuk mengkaji dan menganalisis perlindungan hukum bagi pemegang sertifikat yang beritikad baik?

Penelitian Tesis ini menggunakan penelitian Hukum Normatif menggunakan pendekatan Perundang-Undangan, pendekatan konseptual dan Pendekatan Kasus. tekhnik pengumpulan bahan hukum menggunakan tekhnik studi kasus dengan menggunakan analisis penafsiran Ekstensif sebagai analisis bahan hukum.

\section{PEMBAHASAN}

Kriteria-Kriteria Sertifikat Hak Milik Atas Tanah Sebagai Alat Bukti Hak Yang Kuat

Sistem publikasi yang dianut dalam pendaftaran tanah di Indonesia adalah sistem publikasi negatif bertendensi positif. Sistem ini dipilih karena karakter hukum tanah Indonesia yang bersifat komunal dalam arti tanah selain dapat dimiliki secara perseorangan namun peruntukannya tetap harus berfungsi sosial dalam arti seseorang harus benar-benar mengusahakan tanahnya sesuai dengan peruntukan dan pengusahaan tersebut tidak boleh merugikan orang lain.

pemerintah melalui Pasal 32 PP Nomor 24 Tahun 1997 tentang Pendaftaran Tanah mulai menerapkan bahwa sertifikat tanah yang telah terbit selama 5 tahun merupakan alat pembuktian yang kuat.

Adapun Sertifikat tanah yang telah diterbitkan mempunyai kekuatan pembuktian yang kuat sebagaimana tercantum dalam Pasal 19 UUPA jika memenuhi Kriteria-Kriteria tertentu, adapun Kriteria-Kriteria tersebut adalah : ${ }^{2}$

a. Sertifikat hak atas tanah diperoleh dengan itikad baik;

b. Pemeganghakatastanah harus menguasai secara nyata tanahnya;

Sejalan dengan itu, menurut Urip Santoso, bahwa sertifikat hak milik atas tanah dapat dijadikan sebagai alat bukti hak yang kuat bahkan mutlak jika telah memenuhi kriteria-kriteria sebagai berikut $:^{3}$

1. Sertifikat hak milik atas tanah tersebut diterbitkan secara sah atas nama orang atau badan hukum;

2. Bahwa tanah tersebut diperoleh dengan itikad baik;

3. Bahwa tanah tersebut dikerjakan secara nyata; dan

4. Bahwa dalam waktu 5 (lima) tahun sejak diterbitkannya sertifikat tersebut tidak ada yang mengajukan keberatan secara

\footnotetext{
2 Boedi Harsono, Op Cit, Hlm. 223.

${ }^{3}$ Urip Santoso, Pendaftaran dan Peralihan Hak Atas Tanah, cet,2, Jakarta, kencana, 2010, Hlm 261.
} 
tertulis kepada pemegang sertifikat dan kepala kantor pertanahan kabupaten/ kota setempat maupun tidak mengajukan gugatan kepengadilan mengenai penguasaan atau penerbitan sertifikat.

Dalam hal ini, menurut penulis bahwa kriteria-kriteria yang harus di penuhi agar sertifikat hak milik atas tanah dapat dijadikan sebagai alat bukti hak yang kuat selain sebagaimana yang telah di uraikan diatas adalah bahwa dalam proses penerbitan sertifikat tersebut harus melalui prosedur ketentuan peraturan perundangperundangan yang berlaku. Ketentuan peraturan-peraturan perundangan yang di maksud yakni Peraturan Pemerintah Nomor 24 tahun 1997 tentang pendaftaran tanah dan Peraturan menteri Agraria / Kepala Badan Pertanahan Nasional Nomor 3 Tahun 1997 tentang pelaksanaan peraturan pemerintah Nomor 24 Tahun 1997 tentang Pendaftaran Tanah. Sertifikat hak milik atas tanah dibuat oleh pemegang hak yang beritikad baik, sertifikat hak milik atas tanah diterbitkan oleh pejabat yang berwenang dan obyek tanah dikuasai serta dikerjakan secara nyata secara terus menerus lebih dari 5 tahun.

Tentunya dalam hal ini penulis akan menjabarkan kriteria-kriteria sertifikat hak milik atas tanah sebagai alat bukti hak yang kuat sebagai berikut :

\section{Proses penerbitan sertifikat hak milik atas tanah harus melalui prosedur-prosedur atau mekanisme ketentuan peraturan perundang-pe- rundangan yang berlaku}

Sertifikat hak milik atas tanah merupakan produk hukum yang di buat dan diterbitkan oleh instansi Kementerian Agraria dan Tata Ruang/ Badan Pertanahan Nasional. pengertian sertifikat hak milik atas tanah menurut Pasal 1 angka 20 Peraturan Pemerintah Nomor 24 Tahun 1997 tentang Pendaftaran Tanah adalah surat tanda bukti hak sebagaimana dimaksud pada pasal 19 ayat (2) huruf c Undang-Undang Pokok Agraria untuk hak atas tanah, hak pengelolaan, tanah wakaf, hak milik atas satuan rumah susun dan hak tanggungan yang masing-masing sudah dibukukan dalam buku tanah yang bersangkutan.

Menurut Pasal 1 angka 1 Peraturan Pemerintah Nomor 24 Tahun 1997 tentang Pendaftaran Tanah menyatakan bahwa pendaftaran tanah merupakan "rangkaian kegiatan yang dilaksanakan oleh Pemerintah yang meliputi, pengumpulan, pengolahan, pembukuan, dan penyajian serta pemeliharaan data fisik dan data yuridis dalam bentuk peta dan daftar mengenai bidang-bidang tanah dan satuansatuan rumah susun, termasuk pemberian surat tanda bukti haknya sebagai bidangbidang tanah yang sudah ada haknya dan hak milik atas satuan rumah susun serta hak-hak tertentu yang membebaninya".

Agar subyek hukum pemohon hak milik atas tanah dapat memperoleh kepastian hukum kepemilikan hak atas tanah yakni berupa sertifikat, maka harus dilalui melalui berbagai tahapan yang telah di tetapkan oleh pemerintah berdasarkan Peraturan Pemerintah Nomor 24 tahun 1997 tentang pendaftaran tanah dan Peraturan menteri Agraria Nomor 3 Tahun 1997 tentang Ketentuan Pelaksanaan Peraturan Pemerintah Nomor 24 Tahun 1997 tentang Pendaftaran Tanah.

\section{Sertifikat Hak Milik Atas Tanah di Buat Oleh Pemegang Hak Yang beriktikad baik}

Sertifikat hak milik atas tanah diterbitkan oleh instansi kementerian Agraria dan Tata Ruang/Kepala Badan Pertanahan Nasional atas dasar permohonan Pemegang Hak yang beritikad baik atas obyek tanah. dalam hal pengajuan permohonan penerbitan sertifikat hak milik atas tanah, maka permohonan tersebut di mohonkan oleh pemegang hak atas tanah yang di dasari dengan itikad baik. 
Dadi Arja Kusuma, Rodliyah, Sahnan |Sertifikat Hak Milik Atas Tanah Sebagai Alat Bukti Hak.....

Kamus Besar Bahasa Indonesia memberikan pengertian itikad baik dengan kepercayaan, keyakinan yang teguh, maksud, kemauan yang baik. ${ }^{4}$

Wirjono Prodjodikoro memberikan batasan itikad baik dengan istilah "dengan jujur" atau "secara jujur".

Itikad baik juga dibedakan dalam sifatnya yang subjektif dan objektif. Pada itikad baik yang subjektif, orang memperhatikan sikap dan tingkah laku yang nyata dari subjek. Pada itikad baik yang objektif atau hal yang sesuai dengan akal sehat dan keadilan, dibuat ukuran objektif untuk menilai keadaan sekitar perbuatan hukumnya (penilaian menurut norma-norma yang objektif).

Wirjono Prodjodikoro membagi itikad baik menjadi dua macam, yaitu: ${ }^{6}$

a. Itikad baik pada waktu mulai berlakunya suatu hubungan hukum. Itikad baik disini biasanya berupa perkiraan atau anggapan seseorang bahwa syarat-syarat yang diperlukan bagi dimulai hubungan hukum telahterpenuhi.Dalamkonteksini hukummemberikanperlindungankepada pihak yang beritikad baik, sedang bagi yang beritikad tidak baik (tekwader trouw) harusbertanggungjawabdanmenanggung risiko. Itikad baik semacam ini dapat disimak dari ketentuan Pasal 1977 ayat (1) KUH Perdata dan Pasal 1963 KUH Perdata, dimana terkait dengan salah satu syarat untuk memperoleh hak milik atas barang melalui daluwarsa. Itikad baik ini bersifat subjektif dan statis.

b. Itikad baik pada waktu pelaksanaan hak-hak dan kewajiban-kewajiban yang

4 Tim Penyusun Kamus Pusat Pembinaan dan Pengembangan Bahasa Departement Pendidikan dan Kebudayaan, Kamus Besar Bahasa Indonesia, Edisi II, (Jakarta: Balai Pustaka, 1995) hlm. 60

5 Soetojo Prawirohamidjojo, Itikad Baik (Goede Trouw/Good Faith), Pidato dalam Rangka Memperingati Dies Natalis XXXVIII Universitas Airlangga, Surabaya, 11 November 1992, hlm.3.

${ }^{6}$ Wirjono Prodjodikoro, Asas-Asas Hukum Perdata, (Bandung: Sumur, 1992), hlm.56-62. termaktub dalam hubungan hukum itu. Pengertian itikad baik semacam ini sebagaimana diatur dalam Pasal 1338 ayat (3) KUH Perdata adalah bersifat objektif dan dinamis mengikuti situasi sekitar perbuatan hukumnya. Titik berat itikad baik disini terletak pada tindakan yang akan dilakukan oleh kedua belah pihak, yaitutindakan sebagaipelaksanaan sesuatu hal.

Tentunya setelah sertifikat hak milik atas tanah di buat oleh pemegang hak atas tanah yang didasari dengan Itikad baik di dalam permohonan penerbitan sertifikat hak milik tersebut, maka secara hukum, sertifikat tersebut dapat dijadikan sebagai alat bukti hak yang kuat terhadap kepemilikan terhadap suatu obyek tanah.

\section{Sertifikat Hak Milik Atas Tanah Diterbitkan Oleh Instansi Yang Ber- wenang}

Suatu sertifikat hak milik atas tanah agar dapat memiliki kekuatan pembuktian yang kuat harus memenuhi salah satu kriteria dalam penerbitannya dilakukan oleh Instansi yang berwenang dalam menerbitkan sertifikat hak milik atas tanah. Pejabat yang berwenang dalam hal menerbitkan suatu sertifikat hak milik atas tanah adalah Kepala Kantor Kementerian Agraria dan Tata Ruang/Badan Pertanahan Nasional.

Kewenangan Kementerian Agraria dan Tata Ruang/Badan Pertanahan Nasional dalam menerbitkan sertifikat diatur di dalam Peraturan Kepala Badan Pertanahan Nasional Republik Indonesia Nomor 2 Tahun 2013 tentang Pelimpahan Kewenangan Pemberian Hak Atas Tanah Dan Kegiatan Pendaftaran Tanah. Hal tersebut tepatnya di atur pada bagian III pasal 12 dan Pasal 13 serta Bab IV tentang kewenangan kegiatan pendaftaran tanah Pasal 14 dan Pasal 18 
Kewenangan yang diperoleh Kementerian Agraria dan Tata Ruang/Badan Pertanahan Nasional dalam menerbitkan sertifikat hak milik atas tanah merupakan kewenangan yang bersumber secara atributif yakni pemberian wewenang pemerintahan oleh pembuat undang-undang kepada organ pemerintahan.

\section{Obyek tanah dikuasai serta dik- erjakan secara nyata secara terus menerus lebih dari 5 tahun}

Kriteria yang terakhir agar sertifikat hak milik atas tanah yang dimohonkan oleh pemegang hak atas tanah memiliki kekuatan pembuktian yang kuat, yakni bahwa obyek tanah yang dikuasainya harus dikerjakan secara nyata dan secara terus menerus selama lebih dari 5 tahun.

Jika kita merujuk pada Pasal 24 ayat 2 Peraturan Pemerintah Nomor 24 Tahun 1997 tentang pendaftaran tanah yang menyatakan bahwa :

"Dalam hal tidak atau tidak lagi tersedia secara lengkap alat-alat pembuktian sebagaimana dimaksud pada ayat (1), pembukuan hak dapat dilakukan berdasarkan kenyataan penguasaan fisik bidang tanah yang bersangkutan selama 20 (dua puluh) tahun atau lebih secara berturut-turut oleh pemohon pendaftaran dan pendahulupendahulunya, dengan syarat:

a. Penguasaan tersebut dilakukan dengan itikad baik dan secara terbuka oleh yang bersangkutan sebagai yang berhak atas tanah, serta diperkuat oleh kesaksian orang yang dipercaya;

b. Penguasaan tersebut baik sebelum maupun selama pengumuman sebagai mana dimaksud dalam pasal 26 tidak dipermasalahkan oleh masyarakat hukum adat atau desa kelurahan yang bersangkutan ataupun pihak lainnya.

Penjelasan dalam ketentuan Pasal 24 ayat 2 PP Nomor 24 Tahun 1997 tentang
Pendaftaran Tanah diatas menekankan bahwa subyek hukum yang hendak melakukan penerbitan sertifikat hak atas tanah harus secara nyata menguasai tanah secara fisik selama 20 (dua puluh) tahun atau lebih secara berturut-turut oleh pemohon pendaftaran ataupun pendahulupendahulunya.

Jika kriteria-kriteria sertifikat sebagai alat bukti hak yang kuat telah terpenuhi sebagaimana yang telah dikemuakan di atas, maka secara pasti dan nyata, akan memberikan kepastian hukum bagi pemegang sertifikat hak milik atas tanah, jika pada suatu saat nanti adanya gangguan atau gugatan dari pihak lainnya. Tentunya hal ini sejalan dengan teori kepastian hukum yang dikemukakan oleh J.M. Otto yang dikutip oleh Sri Djatmiati, kepastian hukum (rechtszekerheid) memiliki unsurunsur sebagai berikut : ${ }^{7}$

a) Adanya aturan yang konsisten dan dapat diterapkan yang ditetapkan negara.

b) Aparat pemerintah menerapkan aturan hukum tersebut secara konsisten dan berpegang pada aturan hukum tersebut.

c) Rakyatpadadasarnyatundukpadahukum.

d) Hakim yang bebas dan tidak memihak secara konsisten menerapkan aturan hukum tersebut.

e) Putusanhakim dilaksanakan secara nyata.

Sehingga, ketika kriteria-kriteria sertifikat sebagai alat bukti hak yang kuat telah terpenuhi, maka pemegang sertifikat hak milik atas tanah dapat mempertahankan hak kepemilikannya dengan alat pembuktian berupa sertifikat hak milik atas tanah yang subyek hukum miliki dan kuasai.

7 Tatiek Sri Djatmiati, Prinsip Izin Usaha Industri Di Indonesia, Disertasi, Program Pasca Sarjana, Unair, Surabaya, 2002, hlm. 18 
Dadi Arja Kusuma, Rodliyah, Sahnan |Sertifikat Hak Milik Atas Tanah Sebagai Alat Bukti Hak.....

\section{Perlindungan Hukum Bagi Pemegang Sertifikat Hak Milik Atas Tanah Yang Beriktikad Baik}

Secara kosepsional, perlidungan hukum terhadap hak-hak individu dan masyarakat adalah merupakan salah satu hak assasi bagi idividu dan masyarakat, dapat berupa perlindungan hukum secara preventif dan perlindungan hukum secara represif. ${ }^{8}$

Menurut pendapat Lili Rasjidi dan B. Arief Sidharta tentang fungsi hukum untuk memberiperlindunganadalahbahwahukum itu ditumbuhkan dan dibutuhkan manusia justru berdasarkan produk penilaian manusia untuk menciptakan kondisi yang melindungi dan memajukan martabat manusia serta untuk memungkinkan manusia menjalani kehidupan yang wajar sesuai dengan martabatnya. ${ }^{9}$

\section{Perlindungan Hukum Secara Pre- ventif Bagi Pemegang Sertifikat Hak Milik Atas Tanah Yang Berik- tikad Baik}

Perlindungan hukum preventif yang diberikan bagi Pemegang Sertifikat Hak Milik Atas Tanah yang beriktikad baik yakni telah di atur di dalam ketentuan Pasal 32 ayat 1 dan ayat 2 Peraturan Pemerintah Nomor 24 Tahun 1997 tentang Pendaftaran Tanah yang menyatakan bahwa:

Ayat 1: "sertifikat merupakan surat tanda bukti hak yang berlaku sebagai alat pembuktian yang kuat mengenai data fisik dan data yuridis yang termuat di dalamnya, sepanjang data fisik dan data yuridis tersebut sesuai dengan data yang ada dalam surat ukur dan buku tanah yang bersangkutan".

Ayat 2: "Dalam hal suatu bidang tan-

${ }^{8}$ Arba, S. H. "The Legal Protection Of Community Rights In Area Spatial Planning Of Mataram City Base On The Local Regulation Number 12 Year 2011.” Jurnal IUS (Kajian Hukum dan Keadilan) 2.1 (2014), hlm. 39.

9 Lili Rasjidi dan B Arief Sidharta, Filsafat Hukum Madzab dan Refleksi, (Bandung : PT. Remaja Rosda Karya, 1994), Hlm. 64. ah sudah diterbitkan sertifikat secara sah atas nama orang atau badan hukum yang memperoleh tanah tersebut dengan iktikad baik dan secara nyata menguasainya, maka pihak lain yang merasa mempunyai hak atas tanah itu tidak dapat lagi menuntut pelaksanaan hak tersebut apabila dalam jangka waktu (5) lima tahun sejak diterbitkannya sertifikat itu tidak mengajukan keberatan secara tertulis kepada pemegang sertifikat dan kepala Kantor Pertanahan yang bersangkutan ataupun tidak mengajukan gugatan ke Pengadilan mengenai penguasaan tanah atau penerbitan sertifikat tersebut."

Ayat (1) pasal ini mengandung makna bahwa sertifikat merupakan alat pembuktian yang kuat dan selama tidak dapat dibuktikan sebaliknya maka data fisik dan data yuridis yang tercantum dalam sertifikat harus diterima sebagai data yang benar. Sedangkan ayat (2) pasal ini lebih menegaskan lagi jaminan kepastian dan perlindungan hukum bagi pemegang sertifikat hak milik atas tanah yang beriktikad baik.

Dalam hal ini juga penulis mengacu Pada Surat Edaran Mahkamah Agung Nomor :07 tahun 2012 tentang Rumusan Hukum Hasil Rapat Pleno Kamar Mahkamah Agung sebagai pedoman pelaksanaan tugas bagi pengadilan khususnya pada poin ke IX yang menyatakan bahwa "Perlindungan harus diberikan kepada pembeli yang beriktikad baik sekalipun kemudian penjual diketahui bahwa penjual adalah orang yang tidak berhak (obyek jual beli tanah), pemilik asal hanya dapat mengajukan gugatan ganti kerugian kepada penjual yang tidak berhak.

Jika melihat ketentuan rumusan yang tercantum pada point IX SEMA Nomor :07 tahun 2012 maka, perlindungan hukum secara nyata di lindungi bagi pembeli yang beriktikad baik, meskipun pembeli tersebut meperoleh obyek tanahnya dari penjual 
yang tidak berhak untuk menjualnya, sedangkan pemilik aslinya hanya dapat menuntut ganti kerugiannya saja. Jika unsur ketentuan diatas dikaitkan dengan perlindungan hukum yang diberikan kepada pemegang sertifikat hak milik atas tanah yang beriktikad baik, maka pemegang sertifikat yang beriktikad baik memperoleh tanah dengan cara menguasai secara nyata dan terus menerus selama bertahun-tahun tanpa adanya keberatan atau gugatangugatan yang diajukan ke pengadilan oleh pihak lain meskipun dikemudian hari objek tanah yang digugat merupakan tanah milik pihak lain, maka pemegang sertifikat yang beriktikad baik secara hukum harus dilindungi terhadap kepemilikan dan penguasaannya terhadap obyek tanah yang telah dikuasai oleh pemegang sertifikat yang beritikad baik, sedangkan pemilik asal tanah yang melakukan gugatan ke pengadilan hanya diberikan ganti kerugian terhadap objek tanah yang telah di sertifikatkan oleh pemegang sertifikat yang beriktikad baik.

2. Perlindungan Hukum Secara Represif Bagi Pemegang Sertifikat Hak Milik Atas Tanah Yang Beritikad Baik

Perlindungan hukum secara Represif bertujuan untuk mencegah terjadinya sengketa, yang mengarahkan tindakan pemerintah bersikap hati-hati dalam pengambilan keputusan berdasarkan diskresi. Perlindungan hukum yang Represif bertujuan untuk menyelesaikan terjadinya sengketa, termasuk penanganannya di lembaga peradilan.

Perlindungan Represif yang diberikan bagi pemegang sertifikat hak milik atas tanah yang beritikad baik dari adanya gugatan-gugatan pihak lain di pengadilan, yakni dengan Lembaga Reschstverwerking dalam penyelesaian sengketa perebutan penguasaan hak milik atas tanah bagi pemegang sertifikat hak milik atas tanah yang beriktikad baik.
Akan tetapi, istilah rechtverwerking masih belum terdapat persamaan persepsi. Boedi Harsono mengartikan rechtverwerking sebagai kehilangan hak. ${ }^{10}$ Menurut Kamus Hukum Belanda-Indonesia yang digunakan dalam konteks Bahasa Indonesia saat ini rechtverwerking adalah pelepasan hak. ${ }^{11}$ Ter Haar mengartikan dengan makna melepaskan sendiri haknya oleh seorang subjek pemegang hak. ${ }^{12}$ Soebekti Poesponoto mengartikan rechtverwerking sebagai penghilangan hak sendiri. ${ }^{13}$ A.P.Parlindungan mengartikan rechtverwerking sebagai lepasnya hak yang sudah dipunyainya. ${ }^{14}$

Studi Kasus Putusan Pengadilan Negeri Sumbawa Besar Nomor : 10/Pdt.G/2010/ PN. Sumbawa Besar.

\section{Para Pihak Yang Berperkara}

Para pihak yang berperkara dalam kasus perdata di Pengadilan Negeri Sumbawa Besar Nomor: 10/Pdt.G/2010/PN. Sumbawa Besar adalah sebagai berikut:

Pihak-pihak yang berperkara :

1. SAIDIN,Umur55Tahun,Jeniskelamin laki-laki, Agama Islam, Pekerjaan Tani, bertempat tinggal di Desa Langam,KecamatanLopok, Kabupaten Sumbawa Besar;

2. MASTARI, Umur 70 Tahun, Jenis kelamin perempuan, Agama Islam, Pekerjaan Tani, bertempat tinggal di dusun maronge bawah desa maronge, kecamatan maronge, Kabupaten Sumbawa Besar.

${ }^{10}$ Boedi Harsono, Hukum Agraria Indonesia Sejarah Pembentukkan Undang-Undang Pokok Agraria, isi dan pelaksanaannya, (Jakarta: Djambatan, 2005), Hlm. 67.

${ }^{11}$ Marjanne Termorshuizen, Kamus Hukum Belanda-Indonesia, (Jakarta: Djambatan, 2002), Hlm. 343

${ }^{12}$ Herman Soesangobeng, Komentar dan Kritik atas Pelaksanaan Lembaga Rechtsverwerking Dalam Sistem Pendaftaran Tanah Menurut PP Nomor 24 Tahun 1997, Makalah, (Jakarta, 2002), Hlm. 10

${ }_{13}$ Ibid, Hlm 11

${ }_{14}$ A.P. Parlindungan, Pendaftaran Tanah di Indonesia, Cetakan I, (Bandung: Mandar Maju, 1999), Hlm. 128 
Dadi Arja Kusuma, Rodliyah, Sahnan |Sertifikat Hak Milik Atas Tanah Sebagai Alat Bukti Hak.....

selanjutnya disebut sebagai PARA PENGGUGAT;

\section{Melawan}

MARZUKi MUSA, Jenis kelamin Laki-laki, Agama Islam, Pekerjaan Tani, bertempat tinggal di dusun penam raya Desa Langam, Kecamatan Lopok, Kabupaten Sumbawa Besar;

$$
\begin{aligned}
& \text { selanjutnya disebut sebagai } \\
& \text { TERGUGAT. }
\end{aligned}
$$

Adapun kronologis perkara yang terjadi pada Pengadilan Negeri Sumbawa Besar dengan Nomor Putusan : 10/Pdt.G/2010/ PN.SBB adalah adanya pengakuan dari para penggugat yakni saudara Saidin dan Mastari yang mengklaim bahwa objek tanah yang dikuasai oleh pihak Tergugat Marzuki Musa adalah Tanah pusaka milik peninggalan paman para penggugat yang telah meninggal dunia. Akan tetapi, pihak tergugat Marzuki Musa yang telah menguasai tanah selama lebih 52 tahun sejak tahun 1958 dan diterbitkan sertifikat hak milik atas tanah oleh instansi Badan Pertanahan Nasional Kabupaten Sumbawa Besar pada tahun 1982 dan gugatan dari para pengggugat terjadi pada tahun 2010, jika di lihat dari rentang waktu penerbitan sertifikat, maka tergugat menguasai tanah sejak diterbitkan sertifikat hak milik atas tanah yakni selama 28 tahun.

\section{Analisis Penulis dalam Putu- san Perkara Perdata Nomor 10/ Pdt.G/2010/PN.Sumbawa Besar}

Dalam hal ini, penulis ingin mengemukakan mengenai putusan pengadilan negeri Sumbawa Besar yang menyatakan bahwa sertifikat hak milik atas tanah yang di miliki oleh pihak tergugat telah tidak memiliki kekuatan hukum lagi atau di batalkan. Kewenangan untuk melakukan pembatalan atau menyatakan sertifikat hak milik atas tanah tidak memiliki kekuatan hukum mengikat atau batal merupakan kewenangan atau yurisdiksi absolut dari Pengadilan Tata Usaha Negara, Bukan pada Peradilan Umum khusunya Pengadilan Negeri.

Sertifikat hak milik atas tanah yang dikeluarkan atau diterbitkan oleh Kementerian Agraria dan Tata Ruang/ Badan Pertanahan Nasional merupakan suatu Keputusan Tata Usaha Negara. Keputusan tata usaha negara adalah Beschikking.

Beschikking (keputusan atau penetapan) yang merupakan tindakan hukum Publik Tata Usaha Negara dibagi lagi yaitu Interne Beschikking danEksterneBeschikking. Interne Beschikking atau disebut dengan keputusan intern merupakan keputusan yang dibuat untuk menyelenggarakan atau mengatur hubungan antar organ pemerintah, sedangkan Eksterne Beschikking atau keputusan ekstern merupakan keputusan yang dibuat untuk menyelenggarakan atau mengatur hubungan hukum antara pemerintah dengan pihak lain atau antara dua atau lebih alat negara. ${ }^{15}$

Menurut Pasal 1 ayat 9 Undang-Undang No. 51 tahun 2009 tentang Perubahan kedua atas Undang-Undang No. 5 tahun 1986 tentang Peradilan Tata Usaha Negara tentang Peradilan Tata Usaha Negara, Beschikking (keputusan atau penetapan) merupakan suatu penetapan tertulis yang dikeluarkan oleh Badan atau Pejabat Tata Usaha Negara yang berisikan tindakan hukum Tata Usaha Negara yang berdasarkan Peraturan Perundang-undangan yang berlaku, yang bersifat konkrit, individu, dan final, yang menimbulkan akibat hukum bagi seorang atau badan hukum perdata.

Sertifikat hak milik atas tanah yang merupakan KTUN dikarenakan diterbitkan oleh Instansi Badan Pertanahan Nasional, maka secara legalitas yang berwenang

${ }^{15}$ Utrecht, E., 1960, Pengantar Hukum Administrasi Negara Indonesia, Cetakan Keempat, Universitas Padjajaran, Bandung, Hlm.70. 
untuk menyatakan pembatalan terhadap sertifikat hak milik atas tanah adalah Lembaga Peradilan Tata Usaha Negara atau PTUN.

Peradilan Tata Usaha Negara (PTUN) memiliki kewenangan/kompetensi absolut di dalam melakukan pembatalan sertifikat hak milik atas tanah. Kompetensi absolut suatu badan pengadilan adalah kewenangan yang berkaitan untuk mengadili suatu perkara menurut obyek atau materi atau pokok sengketa. Adapun yang menjadi obyek sengketa di Pengadilan Tata Usaha Negara adalah Keputusan Tata Usaha Negara (Beschikking) Yang diterbitkan oleh Badan/Pejabat TUN. Sebagaimana disebutkan dalam pasal 1 angka 9 UU No. 51 Tahun 2009 tentang Perubahan Kedua UU No. 5 Tahun 1986 tentang Peradilan Tata Usaha Negara. Sedangkan perbuatan Badan/Pejabat TUN lainnya baik perbuatan materiil (material daad) maupun penerbitan peraturan (regeling) masing-masing merupakan kewenangan Peradilan Umum dan Mahkamah Agung.

Kompetensi absolut Pengadilan TUN diatur dalam pasal 1 angka 10 UU No. 51 tahun 2009 tentang Perubahan Kedua UU No. 5 Tahun 1986 tentang Peradilan Tata Usaha Negara, yang menyebutkan:

"Sengketa tata usaha Negara adalah sengketa yang timbul dalam bidang Tata Usaha Negara antara orang atau Badan Hukum Perdata dengan Badan atau Pejabat tata usaha negara, baik di pusat maupun di daerah, sebagai akibat dikeluarkannya Keputusan tata usaha negara, termasuk sengketa kepegawaian berdasarkan peraturan perundang-undangan yang berlaku”.

Maka Pengadilan Negeri Sumbawa Besar yang telah mengeluarkan Putusan Nomor :10/Pdt.G/2010/PN.Sumbawa Besar tidak memiliki kewenangan secara absolut untuk membatalkan sertifikat hak milik atas tanah yang dimiliki oleh pihak tergugat.

Kemudian yang menjadi pertimbangan majelis hakim pada Pengadilan Negeri Sumbawa Besar dengan putusan Nomor :10/Pdt.G/2010/PN.Sumbawa Besar yakni adanya Dokumen/ buku letter c dari surat keterangan Desa.

Dalam Pengadilan, bahwa dokumen Letter C juga tidak diterima sebagai tanda bukti pemilikan tanah yang dikenakan pajak, dinyatakan dalam Putusan Mahkamah Agung tanggal 10 Februari 1960 nomor 34/K/Sip/1960, bahwa:

"Surat pethuk pajak bumi/ dokumen Letter C bukan merupakan suatu alat bukti mutlak, bahwa sawah sengketa adalah milik orang yang namanya tercantum dalam dokumen Letter $\mathrm{C}$ tersebut, akan tetapi dokumen itu hanya merupakan suatu tanda siapakah yang harus membayar pajak dari sawah yang bersangkutan".

Itu artinya bahwa majelis hakim Pengadilan Negeri Sumbawa Besar yang memutus perkara perdata dengan putusan Nomor: 10/Pdt.G/2010/PN.Sumbawa Besar yang dalam amar putusannya menyatakan tergugat merupakan pihak yang kalah dalam penguasaan dan pemilikan terhadap obyek tanah yang telah bersertifikat dan dikuasai secara bertahun-tahun merupakan suatu kekeliruan hukum, yang dikarenakan hakim telah salah menerapkan hukum yang mempertimbangkan surat keterangan desa berupa dokumen buku letter churuff sebagai alat bukti kepemilikan tanah mengalahkan kekuatan sertifikat yang dikeluarkan oleh instansi Badan Pertanahan Nasional yang telah di peroleh dengan itikad baik dan dikuasai secara nyata selama bertahuntahun tanpa ada gugatan atau keberatan dari pihak manapun.

Begitu pun juga dalam hukum tanah nasional kita, yakni Undang-Undang nomor 5 Tahun 1960 tentang Peraturan Dasar 
Pokok-Pokok Agraria menganut sistem hukum adat yang tumbuh dan berkembang di dalam masyarakat.

Dalam hukum adat jika seseorang selama sekian waktu membiarkan tanahnya tidak dikerjakan, kemudian tanah itu dikerjakan orang lain yang memperolehnya dengan itikad baik, maka hilanglah haknya untuk menuntut kembali tanah tersebut. Hal inilah yang dalam hukum adat disebut sebagai lembaga rechtsverwerking.

Adapun syarat penerapan lembaga rechtsverwerking adalah sebagai berikut : ${ }^{16}$

a. Mendudukitanahyangsemulamilikorang lain dengan itikad baik;

b. Berlangsung selama sekian waktu; dan

c. Secara terus menerus dan tidak terputus

Namun dengan demikian bila berdasarkan pada teori perlindungan hukum yang di kemukakan oleh Philipus M. Hadjon yakni perlindungan hukum represif, yaitu perlindungan yang arahnya lebih kepada upaya untuk menyelesaikan sengketa, seperti contohnya adalah penyelesaian sengketa di Pengadilan. Bilamana perlindungan hukum represif tersebut dikaitkan dengan teori Penegakkan Hukum yang memiliki Tujuan untuk mencapai hasil-hasil tertentu yang diinginkan dan tujuan hukum merupakan upaya mewujudkan tercapainya ketertiban dan keadilan, serta sejalan dengan Teori Kepastian Hukum yang dikemukakan J.M. Otto yang dikutip oleh Sri Djatmiati, kepastian hukum (rechtszekerheid) yang memiliki unsur-unsur sebagai berikut : ${ }^{17}$

a) Adanya aturan yang konsisten dan dapat diterapkan yang ditetapkan negara.

${ }^{16}$ Ari.S, Hutagalung, Penerapan Lembaga Recstverwerking untuk mengatasi kelemahan sistem publikasi negatif dalam pendaftaran tanah, Hukum dan Pembangunan, Jakarta, 2000, Hlm 210.

17 Tatiek Sri Djatmiati, Prinsip Izin Usaha Industri Di Indonesia, Disertasi, Program Pasca Sarjana, Unair, Surabaya, 2002, hlm. 18 b) Aparat pemerintah menerapkan aturan hukum tersebut secara konsisten dan berpegang pada aturan hukum tersebut.

c) Rakyatpadadasarnyatundukpadahukum.

d) Hakim yang bebas dan tidak memihak secara konsisten menerapkan aturan hukum tersebut.

e) Putusan hakim dilaksanakan secara nyata.

Maka Jika kita melihat berdasarkan putusan perkara perdata dengan putusan nomor : 10/Pdt.G/2010/PN.Sumbawa Besar, yang memutuskan bahwa " pihak tergugat yang telah menguasai tanah secara nyata dengan iktikad baik selama lebih dari 5 (lima) tahun dan telah diterbitkan sertifikat oleh instansi Badan Pertanahan Nasional Kabupaten Sumbawa Besar dinyatakan sebagai pihak yang kalah, maka dalam hal ini majelis hakim pada Pengadilan Negeri Sumbawa Besar yang memeriksa dan mengadili perkara tersebut sama sekali tidak mempertimbangkan ketentuan pasal 32 ayat 2 Peraturan Pemerintah Nomor 24 tahun 1997 tentang pendaftaran tanah dan tidak menerapkan Hukum secara konsisten yang telah di tetapkan oleh negara serta konsep-konsep lembaga rechstverwerking bagi pemegang sertifikat yang beriktikad baik yang telah menguasai tanah secara nyata lebih dari 5 tahun, padahal tergugat selaku pemegang sertifikat yang beriktikad baik telah menguasai obyek tanah selama kurang lebih 52 Tahun yang perolehan tanah tersebut merupakan warisan yang diberikan oleh almarhum orang tua Tergugat, maka sudah sepantasnya tergugat selaku pemegang sertifikat yang beriktikad baik dan telah menguasai tanah selama berpuluh-puluh tahun harus mendapatkan perlindungan hukum secara pasti terhadap kepemilikan dan penguasaan tanah yang dikuasai dan dikelolanya.

\section{SIMPULAN}

Bahwa kriteria-kriteria sertifikat hak milik atas tanah sebagai alat bukti hak yang kuat yakni meliputi : 
- Proses penerbitan sertifikathak milik atas tanah harus melalui prosedur ketentuan peraturan perundang-perundangan yang berlaku;

- Sertifikat Hak Milik atas tanah di buat oleh pemegang hak yang beriktikad baik;

- SertifikatHakMilikatas tanahditerbitkan oleh Instansi yang berwenang; dan

- Obyek tanah dikuasai dan dikerjakan secara nyata serta terus menerus selama lebih dari 5 tahun

Bahwa perlindungan hukum yang diberikan bagi pemegang sertifikat yang beriktikad baik yakni perlindungan hukum secara preventif yakni telah di atur dalam ketentuan pasal 32 ayat 1 dan ayat 2 Peraturan Pemerintah Nomor 24 Tahun 1997 tentang Pendaftaran Tanah dan perlindungan hukum secara represif yakni dengan adanya lembaga Rechstverwerking serta khususnya perlindungan hukum yang diberikan dalam perkara perdata dengan Putusan Nomor 10/Pdt.G/2010/PN.Sumbawa Besar yakni pemegang sertifikat yang beriktikad baik memiliki kepastian hukum kepemilikan terhadap obyek tanah yang dikuasainya berdasarkan ketentuan pasal 32 ayat 2 Peraturan Pemerintah Nomor 24 Tahun 1997 tentang pendaftaran tanah yang mana dalam pasal 32 ayat 2 tersebut mengenal Konsep Lembaga Rechstverwerking yang artinya jika terjadi sengketa tentang kepemilikan dan penguasaan obyek tanah yang mana jika seseorang selama sekian waktu membiarkan tanahnya tidak dikerjakan, kemudian tanah itu dikerjakan oleh orang lain yang memperolehnya dengan iktikad baik serta menguasai tanah tersebut selama bertahun-tahun yakni 5 tahun lebih. maka hilanglah haknya untuk menuntut kembali tanah tersebut.

\section{DAFTAR PUSTAKA}

\section{Buku-buku:}

A.P. Parlindungan, 1999, Pendaftaran
Tanah di Indonesia, Bandung.

B Arief Sidharta, Lili Rasjidi, 1994, Filsafat Hukum Madzab dan Refleksi, Bandung.

Harsono,Boedi,2005, Hukum Agraria Indonesia Sejarah Pembentukkan Undang-Undang Pokok Agraria, isi dan pelaksanaannya, Jakarta.

Harsono,Boedi, 2007, Hukum Agraria Indonesia, Jakarta

Hutagalung,Ari.S, 2000, Penerapan Lembaga Recstverwerking untuk mengatasi kelemahan sistem publikasi negatif dalam pendaftaran tanah, Jakarta,

Prawirohamidjojo, Soetojo, 1992, Itikad Baik (Goede Trouw/Good Faith), Surabaya.

Prodjodikoro, Wirjono, 1992 ,Asas-Asas Hukum Perdata,Bandung.

Santoso, Urip, 2010, Pendaftaran dan Peralihan Hak Atas Tanah, Jakarta.

Termorshuizen,Marijanne,2002, Kamus Hukum Belanda-Indonesia, Jakarta.

Utrecht, E., 1960, Pengantar Hukum Administrasi Negara Indonesia, Universitas Padjajaran, Bandung

\section{Jurnal/Makalah}

Arba, S. H. "The Legal Protection Of Community Rights In Area Spatial Planning Of Mataram City Base On The Local Regulation Number 12 Year 2011." Jurnal IUS (Kajian Hukum dan Keadilan) 2.1 (2014).

Herman Soesangobeng, 2002, Komentar dan Kritik atas Pelaksanaan Lembaga Rechtsverwerking Dalam Sistem Pendaftaran Tanah Menurut PP Nomor 24 Tahun 1997, Makalah, Jakarta.

\section{Perundang-undangan}

Undang-Undang Nomor 5 Tahun 1960, tentang Peraturan Dasar Pokok- 
Dadi Arja Kusuma, Rodliyah, Sahnan |Sertifikat Hak Milik Atas Tanah Sebagai Alat Bukti Hak.....

Pokok Agraria, LN.No. 104 Tahun 1960, TLN.No.2943

Undang-Undang Nomor 51 Tahun 2009 LN.No.160 Tahun 2009 TLN. No.5079 tentang Perubahan Kedua atas Undang-Undang Nomor 5 Tahun 1986 LN.No. 77 Tahun 1986 TLN No.3344 sebagaimana telah diubah dengan Undang-Undang Nomor 9 Tahun 2004 LN.No 35 TLN.No.4380 tentang Peradilan Tata Usaha Negara

Peraturan Pemerintah Nomor 10 Tahun 1961 Tentang Pendaftaran Tanah LN.No.28 Tahun 1961 TLN.No. 2171 Tentang Pendaftaran Tanah yang diganti dengan Peraturan Pemerintah Nomor 24 Tahun 1997 Tentang Pendaftaran Tanah LN.No. 59 Tahun 1997 TLN.No.3696

Peraturan Menteri Negara Agraria/Kepala Badan Pertanahan Nasional Nomor 3 Tahun 1997 tentang Ketentuan Pelaksanaan Peraturan Pemerintah Nomor 24 Tahun 1997 tentang Pendaftaran Tanah

Surat Edaran Mahkamah Agung Nomor 7 Tahun 2012 tentang Rumusan Hukum Hasil Rapat Pleno Kamar Mahkamah Agung Sebagai Pedoman Pelaksanaan Tugas Bagi Pengadilan

Putusan Pengadilan Negeri Sumbawa Besar Nomor : 10/Pdt.G/2010/ PN.Sumbawa Besar 